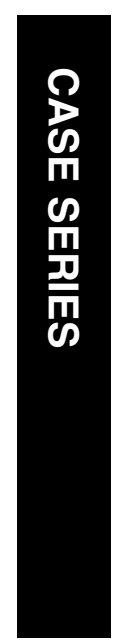

\section{Outcome of 23-gauge sutureless transconjunctival vitrectomy for endophthalmitis}

\author{
Abstract \\ Purpose To review the outcomes of 23-gauge \\ transconjunctival vitrectomy in patients with \\ postoperative endophthalmitis. \\ Methods Non-randomized, interventional \\ case series of patients with postoperative \\ endophthalmitis over a 1-year period. \\ Results 23-gauge transconjunctival \\ vitrectomy was performed on 6 patients with a \\ mean age of 67.7 years without intraoperative \\ or postoperative complications. There were no \\ cases of postoperative hypotony or wound \\ leak. The mean change in IOP was $-4.2 \mathrm{mmHg}$ \\ compared to the preoperative IOP $(P=0.239)$. \\ Final VA improved significantly compared to \\ preoperative VA $(P=0.062)$, with VA of at least \\ $20 / 40$ in 5 of 6 patients $(83.3 \%)$. \\ Conclusions 23-gauge transconjunctival \\ vitrectomy is a useful technique for treating \\ postoperative endophthalmitis.
}

CSH Tan, H-K Wong, FP Yang and J-J Lee

Eye (2008) 22, 150-151; doi:10.1038/sj.eye.6702987; published online 26 October 2007

Keywords: endophthalmitis; vitrectomy; transconjunctival; sutureless; complications; intraocular pressure

\section{Introduction}

The advantages of 23-gauge sutureless transconjunctival vitrectomy compared to conventional 20-gauge vitrectomy are shorter surgical $^{1-3}$ and recovery time, ${ }^{1,4}$ and less postoperative discomfort. ${ }^{1}$ We reviewed the outcome of 23-gauge transconjunctival vitrectomy in patients with postoperative endophthalmitis.

Case report

Over a 1-year period, vitrectomy was performed on six patients (four acute and two chronic
The Eye Institute at Tan Tock Seng Hospital, National Healthcare Group,

Singapore, Singapore

Correspondence: CSH Tan, Department of

Ophthalmology,

The Eye Institute at

Tan Tock Seng Hospital, 11 Jalan Tan Tock Seng, Singapore 308433,

Singapore

Tel: + 6563577726 ;

Fax: + 6563577718

E-mail: Colintan_eye@

yahoo.com.sg

Received: 3 June 2007 Accepted in revised form: 16 August 2007

Published online:

26 October 2007
Table 1 Characteristics of endophthalmitis patients who underwent 23-gauge vitrectomy

\begin{tabular}{|c|c|c|c|c|c|c|c|c|c|c|c|c|}
\hline Patient & Age & Sex & Type & Culture & Surgery & $\begin{array}{l}\text { Duration } \\
\text { of surgery } \\
\text { (min) }\end{array}$ & $\begin{array}{c}\text { Pre- } \\
\text { operative } \\
\text { VA }\end{array}$ & $\begin{array}{l}\text { VA on } \\
1 P O D\end{array}$ & $\begin{array}{c}\text { Final } \\
\text { (stable) } \\
\text { VA }\end{array}$ & $\begin{array}{c}\text { Pre- } \\
\text { operative } \\
\text { IOP }\end{array}$ & $\begin{array}{l}\text { Post- } \\
\text { operative } \\
\text { IOP }\end{array}$ & $\begin{array}{l}\text { Clinical } \\
\text { findings } \\
1 P O D\end{array}$ \\
\hline 1 & 75 & Female & Acute & Enterococcus & $\begin{array}{l}\text { TPPV, AC } \\
\text { washout }\end{array}$ & 50 & LP & $20 / 40$ & $20 / 20$ & NA & 16 & $\begin{array}{l}\text { Corneal } \\
\text { oedema, } \\
\text { fibrin }\end{array}$ \\
\hline 2 & 58 & Female & Acute & $\begin{array}{l}\text { Coagulase } \\
\text { negative } \\
\text { Staphylococcus }\end{array}$ & $\begin{array}{l}\text { TPPV, AC } \\
\text { washout }\end{array}$ & 50 & CF & CF & $20 / 20$ & 18 & 21 & $\begin{array}{l}\text { Conjunctiva } \\
\text { injection, } \\
\text { cornea } \\
\text { oedema, } \\
\text { Descemet's } \\
\text { membrane } \\
\text { folds }\end{array}$ \\
\hline 3 & 76 & Male & Acute & $\begin{array}{l}\text { Coagulase } \\
\text { negative } \\
\text { Staphylococcus }\end{array}$ & $\begin{array}{l}\text { TPPV, AC } \\
\text { washout, } \\
\text { removal of } \\
\text { IOL }\end{array}$ & 70 & HM & HM & CF & 21 & 21 & $\begin{array}{l}\text { Corneal } \\
\text { oedema, } \\
\text { conjunctiva } \\
\text { injected }\end{array}$ \\
\hline 4 & 80 & Female & Acute & No growth & $\begin{array}{l}\text { TPPV, AC } \\
\text { washout }\end{array}$ & 40 & LP & CF & $20 / 40$ & 18 & 16 & $\begin{array}{l}\text { Corneal } \\
\text { oedema, } \\
\text { Descemet's } \\
\text { membrane } \\
\text { folds }\end{array}$ \\
\hline 5 & 54 & Female & Chronic & No growth & $\begin{array}{l}\text { TPPV, } \\
\text { removal of } \\
\text { IOL, AC } \\
\text { IOL implant }\end{array}$ & 75 & $20 / 400$ & $20 / 400$ & $20 / 25$ & 20 & 12 & $\begin{array}{l}\text { Descemet's } \\
\text { membrane } \\
\text { folds }\end{array}$ \\
\hline 6 & 63 & Male & Chronic & $\begin{array}{l}\text { Presumed } \\
\text { P. Acnes }\end{array}$ & TPPV & 65 & LP & HM & $20 / 40$ & 32 & 18 & $\begin{array}{l}\text { Subcon- } \\
\text { junctival } \\
\text { hemorrhage }\end{array}$ \\
\hline
\end{tabular}

AC, anterior chamber; CF, counting fingers; HM, hand movement; IOL, intraocular lens; LP, light perception; NA, not available; TPPV, Trans pars plana vitrectomy; VA, visual acuity. 
endophthalmitis) (Table 1). The mean surgical and followup duration were $58.3 \mathrm{~min}$ (range:

40-75) and 13.2 months (range: 9-17) respectively.

In all surgeries, thorough clearance of the vitreous base was achieved. Common findings on the first postoperative day were corneal oedema, conjunctival injection, and subconjunctival haemorrhage. No patient experienced severe pain, postoperative hypotony, or wound leak. The mean intraocular pressure (IOP) on the first postoperative day was $17.3 \mathrm{mmHg}(\mathrm{SD} \pm 3.4$, range: $12-21 \mathrm{mmHg}$ ), with a mean change of $-4.2 \mathrm{mmHg}$ compared to the preoperative IOP $(P=0.239)$. There were no cases of prolonged postoperative inflammation, or complications such as retinal detachment or macular hole formation.

Final visual acuity (VA) was significantly improved compared to preoperative VA $(P=0.026)$, and was $20 / 40$ or better in 5 of 6 patients $(83.3 \%)$ overall and 3 of 4 patients $(75 \%)$ with acute endophthalmitis.

\section{Comment}

Our study demonstrates that 23-gauge transconjunctival vitrectomy can be performed safely for both acute and chronic endophthalmitis. Postoperative-wound leak and hypotony have been reported with 25- and 23-gauge transconjunctival vitrectomy systems ${ }^{1-5}$ and may be associated with the removal of peripheral vitreous gel. ${ }^{1}$ No patient in our series developed hypotony or subconjunctival bleb formation after surgery.

Increased flexibility of 25-gauge instruments may make complex surgeries more challenging since torsion of the eye is more difficult. ${ }^{1}$ With 23 -gauge vitrectomy, we were able to indent the eye and clear the vitreous base thoroughly without difficulty.
Visual acuity improved significantly in our patients, with results similar to or better than that reported in reports of elective vitrectomies using 25-gauge systems. ${ }^{3-5}$ The poor VA of patient 3 was due to pre-existing glaucoma and macular pucker.

In conclusion, 23-gauge transconjunctival vitrectomy can be performed safely in patients with postoperative endophthalmitis with no complications or hypotony, and good final VA.

\section{Acknowledgements}

We have not received any financial support in the conduct of this research and do not have any financial or proprietary interest in the subject discussed.

\section{References}

1 Chen E. 25-Gauge transconjunctival sutureless vitrectomy. Curr Opin Ophthalmol 2007; 18: 188-193.

2 Fine HF, Iranmanesh R, Iturralde D, Spaide RF. Outcomes of 77 consecutive cases of 23-gauge transconjunctival vitrectomy surgery for posterior segment disease. Ophthalmology 2007; 114: 1197-1200.

3 Oshima Y, Ohji M, Tano Y. Surgical outcomes of 25-gauge transconjunctival vitrectomy combined with cataract surgery for vitreoretinal diseases. Ann Acad Med Singapore 2006; 35: 175-180.

4 Lakhanpal RR, Humayun MS, de Juan Jr E, Lim JI, Chong LP, Chang TS et al. Outcomes of 140 consecutive cases of 25-gauge transconjunctival surgery for posterior segment disease. Ophthalmology 2005; 112: 817-824.

5 Byeon SH, Chu YK, Lee SC, Koh HJ, Kim SS, Kwon OW. Problems associated with the 25-gauge transconjunctival sutureless vitrectomy system during and after surgery. Ophthalmologica 2006; 220: 259-265. 